Article

\title{
Faith and Forgetfulness: Homo Religiosus, Jean-Louis Chrétien, and Heidegger
}

\author{
Jason W. Alvis \\ Institute for Philosophy, University of Vienna, Universitätsring 1, 1010 Wien, Austria; \\ jason.wesley.alvis@univie.ac.at
}

Received: 8 February 2019; Accepted: 8 April 2019; Published: 12 April 2019

check for updates

\begin{abstract}
Religion often is conceived as the sine qua non of the human, thus imbedding religious activity implicitly even within our cosmopolitical globalization processes and secular political concepts. This depiction of the human as ever-religious raises a host of concerns: Does it justify that we can believe ourselves to hold a religious identity without any existential choice or faith? Would it entail the presumption of God's existence, thus possibly leading to God's becoming a banal Faktum that inhibits the subject from being able to disavow God or not believe? And finally, how is it possible to relate authentically/existentially with our religious life without disregarding this quality of religion as always already operative? In order to provide more specificity to this latter question in particular, this paper focuses on an essential aspect of homo religiosus: faith. Focusing principally upon Heidegger and Jean-Louis Chrétien, this paper develops three ways "forgetfulness" is indispensable to faith; or in another sense, how faith itself also operates in, and is acheived through implicit ways. Indeed, if forgetting is essential to faith, and faith is essential to homo religiosus, then "forgetting" also to some degree is essential to religious life.
\end{abstract}

Keywords: faith; forgetting; phenomenology; Chrétien; Heidegger

"Without forgetting, it is utterly impossible to live at all." —Friedrich Nietzsche (Nietzsche 1995, p. 89)

Religion has been described as the sine qua non of the human (Scheler 2010), making homo religiosus relevant for understanding: humans particularly disposed to religious life (Eliade 1969), religion as an implicitly imbedded operation in our processes of globalization (Derrida 1998), the politicization and secularization of theological concepts (Schmitt et al. 2010), and a permanently effervescent form motivating even the "faith for the faithless" (Critchley 2010). ${ }^{1}$ The idea of Religion as the sine qua non of the human, at its core, entails that the human always acts religiously, even if religiosity is denied. Such a depiction may be a necessary outcome of certain aspects of Augustinian theology, which conceives the soul as the housing of God that ever precedes our relation to the world. This "undeniable facticity" (Marion 2002, p. 270) of God follows from Augustine's interior intimo meo et superior summon meo (Confessions III, 6) - that which is more interior to me than my most interiority, and higher than my highest possibility. In Hörer des Wortes (Rahner and Metz 1963), Rahner builds upon this insight through the development of the notion of a "supernatural transcendental", according to which the human permanently is opened to the Absolute, and thus God is required in order for the very possibility of God to be made "meaningful" (potentia oboedentialis). ${ }^{2}$ Some have concluded therefore that everyone

1 Critchley is convinced that even "those who cannot believe still require religious truth and a framework of ritual in which they can believe" for an experience of faith. He takes inspiration from Oscar Wilde who laments the need for a "cofraternity of the faithless" for even "agnosticism should have its ritual no less than faith." (Critchley 2010, p. 3).

2 See, here, Jeffrey Bloechl's excellent engagement of Rahner vis Lacoste on this very problem in his "Being without God" (2010, especially pp. 35-36). For him, subverting "a secular a priori" with a "true a priori is religious and, literally, anarchical." 
worships someone or something ultimately, ${ }^{3}$ and one could surmise that in this sense even the secularization of the globe is but an opaque and estranged version of the gospel's dispersion.

Without necessarily disagreeing with these ideas of religiosity as latently operative-which I have organized under the arch of homo religiosus, taking a step beyond Eliade's conception-such depictions raise a host of concerns and questions: Does it increase the likelihood that we can believe ourselves to hold a religious identity without any attendance to individual religious faith (thus relying upon the faiths of others)? Could the presumption of an a priori basic belief in the Absolute then leave God a banal Faktum that inhibits the subject from an existential freedom to disavow God or not believe? And finally—and this is the more particular question my paper will address-if there is an ever-operative, and thus not always explicitly observable way in which religion is active, then how is it possible to relate authentically/existentially with our religious life without disregarding this essential quality of religion as often-operating latently?

The aim of the paper is not to attempt to overcome or make explicit how religion is implicit, as this would amount to attempting to unveil that which by necessity must to some degree remain hidden and inconspicuous. Rather, the aim of this paper is to address, albeit obliquely, how Religion functions latently; how homo religiosus operates with an ever-active religion that nevertheless is overlooked or forgotten. Since a direct attempt to study this implicit nature of "religion"—an often amorphous term that has been theorized, generalized, and defined in hundreds of ways-directly likely would yield little result, this paper instead focuses on a particularly central aspect that is essential to-especially Christian - religion: faith. The paper addresses how the operation of "forgetfulness" is indispensable to faith or in another sense, how faith itself operates also in an implicit way. Indeed, if (a) forgetting is essential to faith; (b) faith is essential to religion; and (c) religion is indispensable to being human, then "forgetting" and concealment also bear a direct relationship to religion.

In Faith as an Option (2014), Hans Joas interrogates the presupposition of Faith, not only as a choice, but also as an entangled and often unconscious activity within modern secularization and its insistences upon autonomy via Protestantism. Joas points to how the suturing of Protestantism and religious individualization was explicated by Troeltsch (who at times had reservations regarding this thesis) according to three key aspects: "the national cultures' gaining of independence .... , the religious individualism of personal conviction ...., and the religious sanctification of this-worldly work." (Troeltsch trans. in Joas 2014, p. 51). Autonomous faith never takes place in a vacuum, yet a true faith concerns "personal appropriation" and internalization of elements of the tradition. 4 When it comes to religion, one does not choose faith the same way one chooses what to order from the menu. Yet simultaneously it is impossible to live without some version of faith. As Falque recently put it, "nothing is harder to believe than the absence of belief" (Falque 2016, p. 80) for even perception—although distinguished from religious decision—involves a kind of faith placed in the world itself. ${ }^{5}$

(Bloechl 2010, p. 37). Bloechl earlier interpreted that "our secularity in fact only suppresses our deeper relation with God." (Bloechl 2010, p. 34).

3 For example, as James K. A. Smith argues: "We all—whether naturalists, atheists, Buddhists, or Christians—see the world through the grid of an interpretive framework-and ultimately this interpretive framework is religious in nature, even if not allied with a particular institutional religion." Or, as he puts it elsewhere in the text, "All discourses and disciplines proceed from commitments and beliefs that are ultimately religious in nature. No scientific discourse (whether natural science or social science) simply discloses to us the facts of reality to which theology must submit; rather, every discourse is, in some sense, religious. The playing field has been leveled. Theology is most persistently postmodern when it rejects a lingering correlational false humility and instead speaks unapologetically from the primacy of Christian revelation and the church's confessional language." (Smith 2006). Smith more recently draws attention to the idea of "Cultural Liturgies" (Smith 2013).

4 Troeltsch makes this point bluntly, "the autonomy of personal and conscience-based conviction cannot mean a radical absence of tradition or a spontaneity entirely of the moment." He concludes that an ideal faith comes about through "a vibrant process of personal appropriation and further development" and the "working through and internalization of historical forces." (Troeltsch 1910, p. 181). See here also (Troeltsch 1925).

5 Indeed, for Falque, religion is not inherent to all matters of "faith", for there is also an ever-operative "perceptive faith", as a belief in the world, that is more originary and fundamental than the decision to believe found in religious faith. 
Thus, a more specific qualification and description of "faith" (as informed by both tradition/setting and existential decision of the will) is essential to how we are to interpret how the human, as homo religiosus, lives with an ever-active religion. ${ }^{6}$ An existentially oriented faith founded on individual choice and religious neutrality is necessary, yet not at the expense of ignoring that the human condition is marked, often contrary to the will, by an ever present and irreducible religiosity. This paper offers a phenomenology of the "lived experience" of faith (focusing primarily upon the Christian tradition), specifically through the topic of forgetting, via Heidegger and Jean-Louis Chrétien. It is not immediately obvious what the value of "forgetting" may be in general, or in relation to faith in particular, in part because we operate according to the cultural preferences for remembrance and the privileging of memorization over forgetting. Yet in a more phenomenological reflection, forgetting is indispensable to experience itself; as Nietzsche notes, "without forgetting, it is utterly impossible to live at all." (Nietzsche 1995, p. 89) By constantly performing the act of remembrance and by retrieving and recollecting ideas from memory, I limit my ability to "grasp" things and make them meaningful within the stream of inner time consciousness. More generally, without the act of letting go and without forgetting, the past threatens to become, as Nietzsche knew, "the gravedigger of the present." (Nietzsche 1995, p. 89).

Forgetfulness likewise is indispensable for acts of faith. Faith is an inherently interpersonal act that is achieved through means other than simply a direct "willing" of faithfulness or trying to be faithful through a recollection of, and reliance upon, past faith acts. Yet since it also is not possible to achieve faith through total surrender or non-willing, faith might be conceived as an active will-against-the-will (as a form of "letting go" or surrendering) in the act of forgetting. Other scholars have investigated faith phenomenologically from a variety of novel and topical perspectives, such as humility/submission, suffering/victory, or openness/expectation, ${ }^{7}$ and this essay contributes to that ongoing discussion by considering the roles forgetting plays in faith as it is enacted in conjunction with how it appears in its being experienced. After briefly addressing a general theory of "forgetting", then investigating the work of these two thinkers, the essay then outlines three ways forgetting can be conceived as essential to the faith experience, which as mentioned, is a key to understanding how homo religiosus has an ever-operative religious drive or impulse.

\section{Forgetting and Manifestation as Un-Forgetting}

Forgetting (or "un-getting") can be understood fundamentally according to how we experience the manifestation of truth. A-letheia $(\dot{\alpha} \lambda \dot{r} \theta \varepsilon\llcorner\alpha)$ is rooted in lethe $(\lambda \dot{r} \theta \eta)$ or "forgetting." Once the privative alpha " $\alpha$ " is added to lethe, truth becomes, straightforwardly, "un-forgetting." Lethe also can be translated as "oblivion," (as exemplified in reference to someone as "oblivious" or forgetful), "latent," or "escaping notice" (lanthanein). However, what is latent still is present and capable of

There is "no religious faith beyond philosophical faith—that is, no belief in God independently of belief in the world ... " (Falque 2016, p. 89).

6 This is not unlike what Westphal has emphasized throughout his career: "existential phenomenology reminds the theologian that, while 'seeing is believing' ... believing is not necessarily seeing. [ . . . ] I can sincerely believe that my sins are forgiven by the grace of God and that justification is a gift and not a form of wages and still see myself as carrying a load of guilt that I must work off with pious practices." (Westphal 2009, p. 272).

7 Simmons leverages an approach to faithfulness between hope and disappointment: "Following Kierkegaard, when we strive to become faithful, we live victoriously here and now, finding energy for continued action in the already victorious goodness of God. When we try to be successful, alternatively, we are always disappointed because we can never do enough" (Simmons 2017, p. 33). Although Westphal has addressed faith from a variety of standpoints, one that stands out in particular is his "Kierkegaard's Phenomenology of Faith as Suffering". There Westphal points out: "For Kierkegaard's phenomenology of faith as a practice essentially involving suffering is indeed, if you like, a deconstructive dialectic in which more than one stage on life's way is exposed in its immediacy and challenged to abandon its unchecked vitality, acknowledging its other and thus its place of relative importance in a larger scheme of things." (Westphal 1991). Or as Joanna Hodge (whose work I will return to later) claims, regarding a shift of faith, "My hypothesis is that from the human perspective of finite time, there is care, limitation, preoccupation, fallenness, thrownness and projection; whereas with the assistance of the divine gift of love, care is transformed into joy, and faith and hope open out the possibility of a retrieval of a divine illumination which, once given, permits the anticipation of the life to come." (Hodge 2006, p. 38). 
emerging or developing despite being absent from conscious awareness: the related Latin latentem (latere "to be hidden") concerns the dormant, secretive, or unknown. As un-forgetting, truth could be understood thusly as a remembrance that has gone through the trial of loss that forgetting instantiates. Truth's manifestation involves not only the discovery of the forgotten, but also a reliance upon the covered over. Without a prior act of forgetting, truth becomes merely truth-as-disclosure and thereby loses its power to affect us deeply towards action and towards seeking further truth.

Yet Lethe has not always been understood in this more morally neutral sense. Greek mythology (whose heavy influence upon especially Christian Hamartiology is conspicuous) depicts the goddess Lethe personified as a river flowing endlessly through Hades. The river, whose sounds produced feelings of drowsy drunkenness, was said to have been drank from by the inhabitants of Hades in order to attain "forgetfulness" or "unmindfulness" of a past earthly life. Dating to 3rd-century BC Greek Literature, forgetting was even taken to be a sin of committing to non-truth. Apollonius referred to Aithalides, who was gifted with unfailing memory and whose soul was resistant to Lethe. ${ }^{8}$ And in the Republic, Plato suggested that lethe may even be the ur-phenomenon or over-arching representation of the human's flawed earthly existence: when souls faced the penalty of judgment, "a new cycle of life and mortality" (Plato 1990, p. 617) awaited them as they "marched on in a scorching heat in the plain of forgetfulness until they arrived at the river Lethe to drink and then forgot all things." (Plato 1990, p. 621). It is no wonder that the cultural preferences for remembrance and the privileging of memorization came to be a matter of holiness, while forgetfulness came to represent human fallen nature.

Just as forgetfulness is inherent to truth, it is also inherent to faith in an analogous way. Just as forgetting must be a prior act to the unconcealment of truth, forgetting also must be an act within the establishment of faith. Before going into greater detail regarding forgetfulness and faith, it first becomes a question of what kinds of forgetting there might be. It is in this regard that Heidegger, who often referred to the inherent relation between forgetfulness and truth, provides some essential insight. ${ }^{9}$

\section{Heidegger and Forgetting}

There are five different ways Heidegger's references to forgetfulness could be characterized. The first seems to have been initiated already by Husserl to some degree in the context of the natural attitude, of taking for granted (and thereby forgetting) the "world" and "self." Heidegger takes this more critical notion of forgetting or overlooking and embalms it in the hope that things as revealed, provided their being given through Being, are not fundamentally missed, overlooked, or forgotten. The 1946 "Letter on Humanism" depicts the "fundamental experience" of lack of attention to Being as Seinsvergessenheit, or the "forgetfulness of Being" which is a more negative "covering-over" of the clearing of Being. This formulation is referred to throughout his work in a number of ways, such as Lichtungsvergessenheit (clearing-forgetfulness) or Ereignisvergessenheit (appropriation-forgetfulness) that closes over any potential wonder $(\theta \alpha \mathcal{v} \mu \alpha \dot{\zeta}, \varepsilon \iota v)$ at the openness of the meanings and intelligibilities of things.

It is this particular sense of the forgetfulness of Being that Hodge has claimed can be overcome precisely through a certain temporality of anticipation (Vorlaufen) inherent within hope. Although I agree with Hodge that Seinsvergessenheit can in some sense be overcome, one could question to what degree (if at all by necessity) insistence upon forgetting in faith entails "a priority given to futurity."10

8 As described by Apollonius, Aithalides, son of Hermes, gifted with unfailing memory, "has long since been lost in the inexorable waters of the Akheron, yet even so, Lethe (Forgetfulness) has not overwhelmed his soul [unlike the other dead, he remembers his past lives and retains his memory in the underworld]." (Apollonius 1971, sct. 1, p. 642).

9 Heidegger's engagements with religion throughout his career are now well known and highly researched. In this essay, I am instead focusing on the topic of forgetfulness in Heidegger's work so it might teach us something new about faith.

10 As Hodge claims: "I suggest that the notion of hope, in Paul's Epistles, thus can be taken to prefigure the temporal determination of anticipation (Vorlaufen) in Being and Time, and I suggest that the temporality implicit in the notion of faith underpins the thought that the forgetting of being can be overcome." (Hodge 2006, p. 39). Later she refers to how 
Time is not always understood linearly, and the past and future can confer in the present without a necessarily eschatological sense of "waiting" to be shocked by (a pre-judged and pre-determined) something from the outside. Faith, at least in the Christian tradition, is the substance of things hoped for. Yet the way in which one can bracket or set the past aside (a positive sense of forgetting) so as to not remain ignorant (in the negative sense as we learn from Heidegger here) in the present becomes key.

A second sense of Heideggerian forgetting points to how our reliance on technical life has left us oblivious to the overall ontological distinction between Being and beings (Heidegger 1980, p. 360). Such a distinction is what allows us to enter into existential relation with Being or "the clearing" in a way that the concrete, ontic life of the natural attitude (relation with beings) is suspended in preference for what might appear or be given unexpectedly. As Bloechl interprets, "Inauthentic Dasein dreams of a self-sufficiency that is impossible for finite beings; authentic Dasein reconciles itself to that impossibility." (Bloechl 2010, p. 35). It is by living in between these two aspects of Being that their difference can be experienced more fully and productively. Yet we need to relate with an overall awareness of that on which we rely technologically, which remembers on our behalf, and entraps us within the natural or "ontic" attitude. Applied to the topic of faith, this outsourcing of memory further deepens our forgetfulness of the ontological difference, and faith should be considered as that which brings us back to the possibility of authenticity by rendering the ontic as only regional.

Third, there are the varied usages of Verlassenheit (or forsakenness), whether of God (Gottverlassenheit) or Being (Seinsverlassenheit) (Heidegger 1978, p. 53). These more negative kinds of forsakenness stem from forgetfulness. The forgetting of God or Being comes with the consequence of abandonment/forsakenness which refers to how "Being leaves beings to themselves and denies itself to them." When Being abandons beings, their relation with Entbergung or the "unconcealing of Being as such" is putatively absent (Heidegger 1987, pp. 18, 155). This forsakenness amounts to the absence of absence, the absence of withholding, withdrawing, or refusing. Yet we are unaware due to how our sense of abandonment is "veiled." As described in Beiträge zur Philosophie, the three veils (which we ourselves are responsible for constructing) that cover up our general feeling of Seinsverlassenheit are our obsessions with calculation, speed, and "the massive" (massenhaft) a universal or wholesale "applicability" within everyday life (Heidegger 1989, p. 120; Inwood 1999, p. 74).

These veils also can be seen as corresponding to the later interests Heidegger takes in the sacred. The sacred clearing allows for the worlding of the world, yet humankind has "forgotten" this primal, yet hyper-sensual sense of Being. In Hölderlin's "Flight of the Gods" (die Flucht der Götter), such a flight is partly due to the modern machination of the human condition towards a supposedly enlightened progress that has sought to replace one's sacred relations, which are a source of our wonder at Being (Heidegger 1934, p. 80). Yet, as it remains clear from Heidegger's overall work, there is not per se a moral blame to be cast fundamentally at the feet of humankind; the active Wesen of Being or the divine holds an agency that flees on its own accord. Nevertheless, any "salvation" from humankind's technological condition would come in part with a quest for the sacred. This prompts reflection upon faith in a unique way: the forsakenness and flight of God and/or Being (due to the human preference for enlightenment progress and the aforementioned wholesale applicability) entails that forgetting as mystery is putatively absent, thus limiting the agent's sense of intrigue and motivation towards the possibility of what faith can achieve. Although faith "can move mountains", it first remains necessary to believe in faith itself.

Fourthly, for Heidegger, there is also a sense of oblivion inherent within Being, and this is not due to the human forgetting of the ontological difference as Seinsvergessenheit, or any abandonment of the gods. Being withholds a fundamental notion of itself within itself, never to be revealed: "Being does not come to the light of its own essence." And in bringing beings into appearance "Being itself stays

Heidegger's interest in Philippians 3:11-13 entails that "it is not, I think, unsuitable to remark the role here of the notion of forgetting and the priority given to futurity, both important themes left incomplete at the breaking off in the writing of Being and Time." (Hodge 2006, p. 45). 
away. The truth of being escapes us. It remains forgotten." (Heidegger 2002, p. 197). The a priori of Being never fully comes into appearance, for its truth, although recognizable as truth, is held at a distance, ever retaining its element of covered-overness. Nevertheless, this is not a pure privation or simple absence. Being is what brings to present and therefore is the closest of things despite its being forgotten. One does not take interest in the truth in order to bring Being into further manifestation, but rather to be appropriated by its lethe, to be instilled with the wonder of what this Vergessenheit has concealed or withdrawn from presence.

Relatedly, this kind of forgetfulness is not simply a general "forgetfulness." Usually when we realize that we forgot something, we are actually able to trace out the contours of that which was forgotten. In short, we remember that we forgot. For example, I can remember that I have forgotten what year Heidegger gave this seminar, or what I had for breakfast on Tuesday. Yet I do not forget that I had breakfast and in attempting to recover the forgotten, this indicates that it is something with which I still am in relation. In this case, forgetting is also remembering, as I realize that something has been forgotten. In similar terms, we might understand remembering as a bringing to present of the forgotten, for "remembering attempts to overcome forgetfulness by recapturing what was forgotten and making it present again ..." (as Steinbock puts it in regard to Henry, influenced by Heidegger) (Steinbock 1999, p. 279). In short, when remembering that I forgot, the forgetting is not "total," and it is thus a form of (or at least a step within) remembering. This sort of forgetfulness is helpful in thinking about faith in the sense that the forgetting of the past in a faith act need not be a total and complete forgetting, but rather can be a temporary suspension that opens up space and time for one to be fascinated or even appropriated by that which conceals itself uniquely in a way unlike other phenomena.

And fifth, there are indeed cases in which forgetting itself has become forgotten. This amounts to a complete forgetting. In section nine of "Overcoming Metaphysics" (Überwindung der Metaphysik, 1936-1946), Heidegger ties the very process of this overcoming to the "oblivion" or forgetting of Being. Overcoming incorporates this oblivion; it does not seek to unveil everything, for that would decidedly be a means of development championed by our technical and mechanical age. Such an age is exemplified by the total mobilization of nations' ramping up for conflict, as "The 'World Wars' and their 'totality' are already consequences of the abandonment of Being." ("Die 'Weltkriege' und ihre "Totalität' sind bereits Folgen der Seinsverlassenheit."). ${ }^{11}$ The World Wars are a product of the abandonment of Being, which is in part a consequence-paradoxically—of the modern obsession with unveiling, a kind of truth as disclosure. It is a kind of double-forgetting that Chretien insists is an essential aspect of Heidegger's work:

"Heidegger frequently insisted on the doubling of forgetting: to truly forget, forgetting is not yet enough, for forgetting in memory that one has forgotten is only a mode of remembering-a mode that, precisely, permits us to rediscover what was forgotten. Complete forgetting, he shows, is forgetting the forgetting, disappearance of the very disappearance, where the covering over is itself covered over. This doubling, or second power of forgetting must in truth be posed as first: it is not a higher form of forgetting that succeeds another form exponentially, for the forgetting that does not forget itself constitutes on the contrary a first memory, a first opening to overcoming the forgetting.". (Chrétien 2002, p. 2)

This doubling of forgetting is different from a forgetting whereby I still remember the contours of the forgotten - a forgetting that in fact is the first "step" within an act of recollection. Rather, the doubling of forgetting is like the absence of absence mentioned earlier. It concerns what is yet to enter

11 (Heidegger 2000, p. 91). Similarly, he also refers to how mechanization organizes itself: "All dieses ist schon eingespannt in den Mechanismus der Rüstung des Ordnungsvorganges. Dieser selbst ist bestimmt durch die Leere der Seinsverlassenheit, innerhalb deren der Verbrauch des Seienden für das Machen der Technik, zu der auch die Kultur gehört ..." (Heidegger 2000, p. 90). 
phenomenal experience and, in the context of faith, it provides no content for the agent to consider or be affectively influenced by. This reference is also quite similar to a claim by Kierkegaard, whose influence upon both Heidegger and Chrétien is conspicuous:

"one is not ignorant of what is forgotten, since one is ignorant only of what one does not and never has known; what one has forgotten, one has known. Forgetting in this highest sense is therefore not the opposite of recollecting but of hoping ... to forget is in thinking to take away being from that which nevertheless exists, to blot it out ... " (Kierkegaard 1964, pp. 295-96) ${ }^{12}$

This forgetting is a covering over of the remembered, which is still operative by providing an opening.

Applying Heidegger's insights on forgetting to faith, in some cases, a "total" forgetting, a covering over of the covered over, is necessary in order to live according to Chrétien's interpersonal "unhoped-for" (to which I now turn to in the following section). In some cases, a total suspension is necessary so that "remembering" is not the first act of forgetting (remembering that which I forgot, thus placing the remembered in a privileged position once again). Yet, in other cases, a temporary suspension of a particular faith act is what is necessary so as to re-instill a fascination and wonder at something other than that which is within one's own human capacities of memory. As we learn from Heidegger, an act of suspension, which effectively covers over the remembered, can create a new possibility in the present. One can forget, bracket, and set the past aside so as to not remain in ignorance. Faith is what leads us back to authenticity - beyond the outsourcing of our faith to memory-by demonstrating that faith is not merely regional (again, as Heidegger would say, is a result of having forgotten the "ontological difference") but rather that it is applicable across every spectrum of the lifeworld. I now turn to Chrétien, who also holds to a non-regional understanding of religious life.

\section{Chrétien, Hope, and Faith}

Jean-Louis Chrétien, a thinker associated with the pejoratively named "theological turn," is known for developing a phenomenology of Christianity in its experiential or "lived" element. ${ }^{13}$ Throughout his career, he has laid great emphasis upon the call-response orientation of religious experience, which he claims to be prayer itself. Indeed, religion for him "appears and disappears with prayer" (Chrétien 2000, p. 147). Yet at the same time, religion is not simply a "regional" object for phenomenological reflection to investigate, but also a source that can alter phenomenology itself. Religion (a la prayer) is a source of calling us out of nothingness, to which we then respond. More broadly regarding phenomenology and religion's relationship, our finitude (or "wounding") is the very space in which infinitude can break-in. Further, since phenomenology is a set of acts whose intention is a correct description of the world of experience, they can correspond to, and need not be in competition with other acts, such as liturgy, ritual, or prayer. One precise reason for engaging in these activities is to wrestle seriously with truth.

Under Chrétien's development, forgetting becomes a kind of active bringing to truth whereby what is confidently taken to be the case is surrendered in order to be rendered open to what is absent, yet still effective. As a source of religious experience, forgetting is an operation of turning to the means by which the hidden within the non-hidden operates (as the remembered, the already-manifested and made-to-present). It is thus the seeking of, or again, wrestling with, truth at its most fundamental level. Faith is to be understood in relation to Chrétien's notion of the unhoped-for or content of this forgetting,

12 For another study concerning how forgetfulness has been studied, for example, in Freud, Kierkegaard, and Nietzsche, see also Volf, (Volf 2006).

13 For recent studies on Chrétien's balancing between religion and phenomenology, see Andrew L. Prevot, (Prevot 2015). See also Joshua Davis's development of a connection between Henri de Lubac and Chrétien, and he argues how Chrétien employs Heidegger's distinction between manifestation (Offenbarkeit) and revelation (Offenbarung) to defend applying phenomenology towards religious topics (Davis 2010, p. 181). And for more on the question of Chrétien on faithfulness vis-à-vis hopelessness, see J. Aaron Simmons, (Simmons 2017). 
which concerns what is here now, always, and already. As the French l'inespéré refers, this unhoped-for is a hope for what is impossible to ever dream of hoping and to achieve this, forgetfulness must play an essential role.

\subsection{Forgetting and Chrétien}

For Chrétien, it is by turning to the familiar to find something unfamiliar within it that provides a productive confrontation with our overwhelming preferences for a posteriori knowledge. To forget is to offer "to God of memory" and for one to be "stripped of memories and lose them." (Chrétien 2002, p. 77). This is the act by which God enters into memory and renarrates its contents via a Divine surplus, which is what makes this forgetting great: "forgetting alone, if it is great, places us in accord with this excess." (Chrétien 2002, p. 77). There is an interpersonal element at work within this act of forgetting, for the remembered "will be recovered ... but in a different form; it will have become malleable, receptive to divine action, instead of being the organ of attachment to what escapes it or has already escaped." (Chrétien 2002, p. 99). This excessive divine action is what, in this case, waits for us to fulfill our part or role in the forgetting process, and to surrender temporarily the self-sustained ability of remembrance (here, recalling Heidegger's mention of the full-scale obsession with broad applicability of truth as correctness). Forgetting is what ushers our faith into a willfulness to surrender the aforementioned preferences for the a posteriori, and instead to have in its place the goal of being co-participants within the interpersonal faith act.

The task then becomes how we are to be directed towards absence "because memory is the place of presence," which lacks dynamic faith. The role we play in forgetting is an act of kenosis or self-emptying through which "forgetting produces an ignorance of self that is positive." (Chrétien 2002, p. 34). This is why, despite the potential an "uncovering" or even a "correctness" (Adequatio) may provide for religious experience, Chrétien's book The Unforgettable and the Unhoped For "is dedicated to forgetting and its diverse forms". (Chrétien 2002, p. xx). This kenosis is unique in that it is not merely negative. Forgetting is not the emptying out of memory, and there is a productive nature of forgetting in that it "founds and gives." In loosening the conscious grip (Griff) on "the remembered", one is free to forget the past as it does not constitute in total one's humanity-I am not what I remember. Likewise, my present acts of faith are not constituted by my past.

To forget in this sense is also to be in the truth more radically by bracketing the more ontic form of truth that more often than not privileges "uncovering" and revealing in "the present." This allows for closer attendance to what is becoming present and absent. ${ }^{14}$ Chrétien has referred to this as a bracketing of crystalized, past memorialized knowledge or, as he has reiterated this point more recently, "my present condition prohibits me from imagining figuratively." (Chrétien 2015, p. 84). Indeed somewhat enigmatically, this is an active bracketing that takes place in the form of a kenotic prayer: one comes to be-appropriated by the truth that becomes, paradoxically, "unforgettable" (Alastos) by breaking the chains of totality and its illusions of knowing. That is, the truth itself is unforgettable, yet again it is accessed through forgetting.

Chrétien of course is not ignorant of the fact that there are forms of bad-faith immemorialization or forms of forgetting that can amount to a total loss or imprisonment in ignorance. Such forgetting marks our "earthly" condition. It is this notion that compounds into one of Chrétien's greatest insights, which is that this bad-faith form of forgetting (to which Heidegger refers in regards to Seinsvergessenheit and the like) is underwritten by a remembrance or memorialization that is ill conceived. There is an intelligibility that is taken out of context, disguised in the form of a spectacular truth that prohibits further thinking. As opposed to the attempt to eradicate forgetting fully as it is amoral (which

14 (Chrétien 2002, p. xx). For Chrétien, "Attentive study to the Platonic thought of recollection ... shows that this first forgetting constitutes its irreducible nucleus. But this forgetting is a forgetting that founds and gives, a forgetting that opens a properly human temporality, which is that of search for the truth and for oneself." (p. xx). One reason for this is because "the original opening to the truth can not be thought according to the presence of the present." (Chrétien 2002, p. 23). 
the ancient Greek myths of Lethe promulgated), it is necessary to see that the root of this problem "is stimulated not by forgetting itself, and not by the powers of the sensible, but by what of the truth subsists in us." 15

Strangely, it is the remembered that underwrites ignorance, or the ignorance of ignorance. This ignorance also inhibits the unhoped-for. When leaning on past acts, thinking becomes sedimented into habitus or sedated "into acquired dispositions." Hope is not characterized by attempting "to calculate one's conduct in probabilities, thus remaining in the realm of economics. Only the unhoped-for ... is ... the anchor and resource against what is unforeseen in life." (Chrétien 2015, p. 71). There must be a forgetting of forgetting in order to break the spell of ignorance. We can only protect ourselves from life's unforeseeable circumstances by building up hope, namely via forgetting, which breaks down the encrusted deposits within the heart, soul, and mind.

\subsection{Unhope and Potentiality}

Chrétien's idea of the unhoped-for concerns the interrelated matters of possibility and potentiality. For Heidegger, potentiality concerns how all things, no matter how banal or mundane, can act as conduits of Being or of an Uncanniness that "itself in its essence is the inconspicuous, the simple, the insignificant, which nevertheless shines in all beings." (Heidegger 1992, p. 105). The Uncanny tends to give itself in the least expected of spaces, and thus all places, ways, and things bear an instantaneously controvertible intelligibility. This demonstrates Heidegger's description of the meanings of Being according to an inversion of (or at the very least a striking out of the dialectic between) Aristotle's preference for actuality (being-in-energeia, $\varepsilon \vee \varepsilon \rho \gamma \varepsilon\llcorner\alpha$ ) over potentiality (being-in-dunamis, $\delta v v \alpha \mu \iota \varsigma$ ). As Heidegger insisted, yet still in a non-Platonic way, "higher than actuality stands potentiality." (Höher als die Wirklichkeit steht die Möglichkeit) (Heidegger 1962, p. 34, Being and Time/Heidegger 1977, pp. 51-52, Sein und Zeit). The over-preferencing of actuality leaves Being reliant on the terms of objective "presence," thereby subordinating Being's potentiality or possibility to the past. Yet, since all finite things at any time and point can express the uncanny in any present, we also should not be so quick to equate potentiality with futurity that creates faith in, and anticipation for, a promise of something new and spectacular. ${ }^{16}$ What we serve to gain from this corrective is that faith, via forgetting, places potentiality in the here and now without succumbing to a reliance upon past acts of faith (or a metaphysics of presence). It charges every moment-this moment-as a moment of faith.

It is possible to track this sort of potentiality within Chrétien's depiction of the unhoped-for, which functions in association with faith, and is instantiated by an active forgetting. It is unhoped-for because an intention of faith is not capable of controlling what will or could come. It is not in the realm of actuality, of a past experience re-presenting itself, that this hope is based. Put more positively, what we do not hope for is more powerful within us, for it insists on both the intersocial element of a unique kind of surprise, and a humility instantiating patience that involves ultimate trust and faith. If hope were a matter of mere "intending", then faith could be taken as the failsafe key to achieving it. Yet faith "in its how" operates-and is achieved -in a not-so-straightforward way, motivated by the attaining of a unique kind of knowledge (a point to which I will return). Faith is achieved indirectly by not making the faith itself the focal point.

15 (Chrétien 2002, pp. 34-35). As he continues, "The pre-possession—obscure, latent, unarticulated—of truth is that which throws us into the illusion of knowing. That which remains in a sense outside the reach of forgetting, the unforgettable character of what in essence belongs to us, forms what can make us forget supremely and fall into the worst sort of illusion. The pre-possession of science is taken for science: here would be ignorance at its limit." Continuing, "This double ignorance marks the deepest fall, the imprisonment par excellence, since it prohibits even the search for truth and paralyzes our desire. It is from this that philosophy must first and foremost deliver us." (Chrétien 2002, p. 35).

16 Although potentiality/possibility is preferred as a kind of social-corrective here, for Heidegger being actual and being possible are to be understood to hold a synthetic and non-dialectical unity in the present. 


\section{Faith in Its How: The Interpersonal Nature of Faith}

In following Chrétien, if to forget is to make the entirety of one's memory an offering, and if forgetting is inherently a part of the faith act, which is interpersonal by nature, then this interpersonal offering must be understood beyond the traditional interdicts, namely, of being characterized either as "trust" or "creeds" of conviction. Faith is not only the ascent of information or articles of "belief": Nietzsche's proclamation of the "death of God" surely was not the derailing of a culture that had forgotten information about, or ceased to recite creeds regarding God, but rather that they had lost faith in, and reliance upon God. Indeed, faith concerns "the state of being ultimately concerned" (Tillich 2009, p. 231) and being grasped by what "transcends us unconditionally." (Tillich 2009, p. 256).

Yet to reduce faith to "trust" also seems to underemphasize how faith operates with its own evidences aside from what seemingly is trustworthy. Faith indeed is a matter of confidence and fidelity; it is a "trust in that which gives value to the self" and a "loyalty to what the self values" as Richard Niebuhr insisted (Niebuhr 1993). Yet faith is more than trust because it instills an absolute loyalty that no single human (who one could "trust") could ever be capable of conjuring due to finitude and fallibility. The reduction of faith to being only an act of trust runs the risk of overemphasizing the individual choice to trust, and thus of autonomy over heteronomy, potentially detaching the agent from the one in whom she trusts. If faith is interpersonal, then like all interpersonal activities, it requires some element of difference, entailing that an act of faith must also await its complementary faith act. As von Balthasar knew, "faith interiorly strives away from the believer on into the light of God and to the evidence to be found in God alone; but the quaerens must be complemented by an inveniens which is compatible with the earthly state of the believer." (Balthasar 1982, p. 136). Or as Chrétien put it more recently, "One must not for a single moment lose sight of the fact that biblical hope, just like faith, is a personal link with the personal God." (Chrétien 2015, p. 78).

This call for interpersonal faith can be taken in conjunction with the oft-quoted conception of faith developed by the writer (predominantly thought to be St. Paul) of Hebrews 11:1: "Faith is the substance of things hoped-for, the evidence of things unseen." The "unseen" reality has a proof that corresponds to it uniquely. This proof or evidence is faith. Although it has elements of its own self-justification, faith is not a proof like other proofs. Its justification/proof operates according to a circular nature: faith is a produced act of hope, and it is the "filling" or content that inspires hope and brings it to life. It fills one's otherwise abstract wished-for reality with actual content. Faith simultaneously is the content and proof of a wished-for reality. Yet it is also always under threat by a fear of what could disappoint that wished-for reality, and is reflective of a certain ontotheological dependence. One arrives at faith through a heteronomous encounter with the will of an uncontrollable other, thus keeping our solipsistic and xenophobic tendencies at bay. As Westphal interprets Heidegger's alarm of ontotheology, "faith involves overcoming ... the xenophobia that takes place as ontology" (Westphal 2001). ${ }^{17}$

\section{Testimony and Witness as Inherently Interpersonal}

Recalling earlier references to the relationship between forgetfulness and truth, and applying them now to this point of how one communicates about and gives expression to interpersonal faith (or at the very least, takes it beyond xenophobia): the sharing of testimony and the bearing of witness are phenomenal experiences that, by necessity, cannot rely upon past memorialization precisely because that about which/whom one testifies does not assert itself in the form of a universally accepted proof, which makes the testimony necessary. The testimony indeed gains its power from how the testified is

17 Heidegger specifically considers faith in the context of onto-theology and its constitution of metaphysics, which poses, as Westphal interprets "a danger to the life of faith." (Westphal 2001). See, especially, Chapter 12, "Faith as the Overcoming of Ontological Xenophobia." 
not self-evident. Further, the willful part of the act of placing faith in someone is not an act that gets fully accomplished, for the faith act is never "completed" in the sense of having a telic, achievable end. Rather, the placing of faith-in further sustains faith precisely by not asserting itself as thoroughly comprehensible. The faith act (that is, the act itself, not simply the hoped-for result of the faith act) thus entails a certain dependence upon, and representation of the one in whom faith is placed. Testimony proclaims having had an experience of God or the Absolute, and this marks the evidence of the interpersonal nature of faith. All one can express in testimony, as Ricœur argues, is that "the Absolute and its presence is constituted. It is only about this that testimony testifies." (Ricoeur 1980, p. 144).

Yet how then does one testify about the Absolute in any meaningful way, and what is the content of the testified that can be expressed according to some (albeit perhaps minimalistic) positive description? This question is implicit within Heidegger's earliest treatments of Christian life in 1920 where he interpreted St. Paul to provide a new conception of the life of faith as inherently intertwined with the co-constituting and inter-social elements of "proclamation" and "witness" (which Ricœur distinguished from testimony). This intertwining operates in a way that is not about the communication of what one comprehends, but rather of what and how one does not know. Only that for which one awaits in faith and hope and for what could be to come is worthy of "proclamation." 18 What at first appears to be merely an apophatic claim harbors something that is uniquely capable of a positive phenomenological description: Sutured to such a testimony, faith-as-lived is inter-social in its being shared and proclaimed. Faith not only concerns an expression of the past, but also the state of faith in the present. An expression of "faith" sans testimony of the unknown instead concerns some past memorialized knowledge.

Similarly, to witness is to communicate the unknown, how one arrives at its structures of/for the continuation of thought, and "to give witness" is a making-social of the recognition that something is greatly altering the social fabrics of one's life in a radical re-becoming. This witness or testimony is based on the "how structure" of having: having in this paradoxical context in which one decidedly does not "have" faith (e.g., in the way one "has" gold in the bank) instead entails the elucidation of the contents, relations, and enactments of how one bears witness to this unique having itself, its moments of appearing that alter not only the individual life, but also the social tapestry in which one finds oneself. In the context of faith, "having" is a kind of not having or even "forgetting." It is the realization that one does not have and lacks faith that creates potential for suspense for the to-come, further engaging faith. The experience of not having, or even the active and willful suspension of the acknowledgement of what one has or is, can be suspended. In this suspension, something new can appear. ${ }^{19}$ This all supports the necessity of recognizing that faith is an interpersonal phenomenon whose means of being attained is not a matter of only one's own volition.

\section{How to Be Faithful? Forget}

St. Paul's letter to the Philippians has, up to this point, been an important yet implicit undercurrent within this essay, which has sought to draw out some insights regarding forgetting and faith that can lead to a better understanding of how homo religiosus operates with a latent religious drive or activity. Philippians 3:7-14 points explicitly to a relation faith, forgetting, and knowledge can have:

"7 But whatever were gains to me I now consider loss for the sake of Christ. ${ }^{8}$ What is more, I consider everything a loss because of the surpassing worth of knowing Christ Jesus my Lord, for whose sake I have lost all things. I consider them garbage, that I may gain Christ

18 (Heidegger 2010). See, especially, his winter semester seminars of 1920-21, The "Introduction to the Phenomenology of Religion."

19 Although I am using examples specifically from the Christian faith, some of these reflections are not limited to Christianity. I would generally agree (although with some hesitations) with Critchley's claim also that "the faith of the faithless reveals the true nature of faith: the rigorous activity of the subject that proclaims itself into being at each instant without guarantees or security, and which seeks to abide with the infinite demand of love. Faith is the enactment of the self in relation to an infinite demand that both exceeds my power and yet requires all my power." (Critchley 2010, p. 18). 
${ }^{9}$ and be found in him, not having a righteousness of my own that comes from the law, but that which is through faith in Christ-the righteousness that comes from God on the basis of faith. ${ }^{10} \mathrm{I}$ want to know Christ-yes, to know the power of his resurrection and participation in his sufferings, becoming like him in his death, ${ }^{11}$ and so, somehow, attaining to the resurrection from the dead. ${ }^{12}$ Not that I have already obtained all this, or have already arrived at my goal, but I press on to take hold of that for which Christ Jesus took hold of me. ${ }^{13}$ Brothers and sisters, I do not consider myself yet to have taken hold of it. But one thing I do: Forgetting what is behind and straining toward what is ahead. ${ }^{14}$ I press on toward the goal to win the prize for which God has called me heavenward in Christ Jesus."

Suspense (especially in the phenomenological sense of "bracketing" or the epoché) may be a good way also of describing the faith act, which circularly calls for a conversion not only of the self, but of one's past by forgetting not merely what one knows, but also how one has attained faith in the past. As Chrétien understood, the giving-up of one's memory is a worship offering that then can forge new pathways of faith and thus sustain it. Inspired by Chrétien and Heidegger, there are three ways it is possible to imagine how forgetting can be thought to support faith "in its how."

First, forgetting entails a double movement of both opening up to "the new" but also a disclosure of the new from within "the old". As mentioned earlier in the context of faith, forgetting is not simply about hope-as-futurity or a distant to-come eschatology. It is a displacement of aspects of the present so that faith might arise out of places and things that are entirely unexpected, such as that which hitherto had become merely obvious. In a certain limited sense, this aspect of forgetting in faith could be compared to St. Paul's call in the second letter to the Corinthians to "take every thought captive" (10:5) in order for faith to be developed in obedience. Thoughts that are not taken captive rule the mind and life of faith, and instead become the captor themselves through a totalizing control of phenomenalization. By not taking thoughts captive, moral life goes off-track and one attempts to rely upon past faith acts to do the present work of faith. Forgetting temporarily brackets past faith acts and helps take every presupposition captive in favor of opening-up to faith wherever it may be intersecting within the present. This also provides a means by which it is possible to overlook a presently operative condition affecting oneself, and to keep it from providing the overarching intelligibility of a particular experience or event. This holy "setting apart" or "clearing away" of memorialized judgments allows for the possibility of new means of interpersonal faith that are entirely unsuspected by thought. As Chrétien understands, unhoping provides for us precisely what we do not hope for; if we could hope for it, then the provider of one's hopes could be conjured at the will of the hoper.

A second role forgetting can play in regard to faith, after suspending a past memorialized knowledge or faith experience, is that it is the activity that indirectly brings faith about through the attaining of a unique kind of knowledge. Returning to Philippians 3, Paul illustrates the essential nature of forgetting in order to reach the ultimate goal, not of achieving or collecting recallable information about Christ, but rather of knowing Christ as a person. As stated in verses 7-10, this goal is to supersede all other goals. This is an interpersonal knowledge attained by a faith that produces and creates a basis for righteousness, and in order to enact this righteousness, one's own past righteousness, via ethical achievements and self-regulation, must be suspended, overlooked, or forgotten (3:8-9). There is one act of volition that can be engaged to achieve the overall goal of knowing Christ: one can actively forget (3:13). A phenomenology of faith, as Chrétien notes, entails that forgetting "in each instance throws us and opens us to preoccupation with what lies before us" (Chrétien 2002, p. 35) and this is precisely the imagery St. Paul employs, allowing us to imagine faith somewhere in between the act of forgetting and the aim of personal knowledge of Christ.

Third, forgetting can be understood in regard to faith as an active "giving" or "letting". As such, it is not simply the subtraction or negation of a memory, but the active (recalling here the role of the "a" of a-letheia) addition of something to this memory. This forgetting is not an anti-remembrance but more of a counter-remembrance. This "letting" is a letting go of a past experience that stands out as a special achievement in one's life. Heidegger's notion of Gelassenheit (letting-go, leaving-be) points 
towards a state that is both active and passive, and thus found in the middle voice of surrendering. ${ }^{20}$ The giving of memory as an offering is a "letting", allowing, or giving-way for something/someone else to appear so as to keep the past, as Nietzsche put it, from becoming the "gravedigger of the present" (Nietzsche 1995, p. 89).

Although Paul has somewhat different aims than Heidegger and Nietzsche, this praise of forgetting is evident in the letter to the Philippians: "I do not consider myself yet to have taken hold of it [this knowledge of Christ]. But one thing I do: Forgetting what is behind and straining toward what is ahead ..." (3:13). Releasing, giving over, or forgetting ( $\dot{\varepsilon} \pi \iota \lambda \alpha v \theta \alpha v$ ó $\mu \varepsilon v o \varsigma$ epilanthanomenos) certain thoughts and experiences is a key to how knowledge of Christ is achieved, which goes in conjunction with faith in Christ. Broadly conceived, these interpretations of the role of forgetting are within the capacity to attain such knowledge.

\section{Conclusions}

Faith thus concerns an active weakness to go beyond oneself by displacing, reframing, and reimagining the ordinary as infused with the sense of the Absolute. It also involves the active separation between that which one does put faith in (here, related to the spiritual discipline of "discernment" or making distinctions), and that which one does not. Yet it is co-qualified; it is not the subject who "has" faith, for this would also entail a quick reduction to self-faith (trust in one's own faith acts) and self-enclosure, thus amounting to a seizure of relation between oneself and the Absolute. Indeed it is precisely this self-faith and nihilistic self-enclosure that in part marks the crisis from which one yearns to escape through faith!21 As Chrétien puts it elsewhere in regard to prayer: "All prayer ... dispossesses us of our egocentricism." (Chrétien 2000, p. 153).

For the overcoming of such egocentricism and nihilistic self-enclosure, forgetting provides faith a necessary supplement. Forgetting helps instantiate an active attempt to overlook what seems to yearn for our attention (by "putting away of the old") in favor of something else. It is not simply only something "new" that appears, but more radically, a potential disclosure of the new from within "the old" that has been there all along, a futurity within the past so all can be seen anew. When faith is understood through the essential activity of forgetting, it becomes clearer that the means of attaining faith cannot be through a direct attempt to be faithful. One cannot "will" faith into action. Yet it also seems impossible to will a non-willing in efforts to "achieve" more faith. Instead, a middle-voice or an active-passive understanding of faith highlights how it plays an essential role in attaining a kind of interpersonal knowledge whereby the faith act itself is powerful when it is placed out of focus. Similar to the task of driving a car, in which the focus is on the driving and not on the car itself, the act of faith is brought about by an active will to forget so that in a given moment, faith can become powerful and pertinent.

Further, as interpersonal, faith is always a faith-with and therefore cannot be attained solipsistically. Although never fully presenting itself, the "other" of the faith act provides enough phenomenality for the grounding of an experience of faith. As Chrétien insists regarding prayer, the religious phenomenon "par excellence" (Chrétien 2000, p. 147), there is an inherent call and response structure that does not leave the individual only within a silent dialogue with herself (Chrétien 2000, p. 49). It is here that the notion of forgetting needs to be understood as radically inherent within acts of faith $a$ a an active-passive suspension of old beliefs and their produced outcomes so as to participate in faith in the present. That which we characterize as "unforgettable" concerns an experience with that which was never in

20 See Ian Alexander Moore's excellent study of Heidegger's engagement with this topic of Gelassenheit in GA 83, his Seminars on Plato, Aristotle, and Augustine (Moore 2017).

21 Critchley expresses what the crisis is and what the solution is in different terms. Yet he still conceives faith similarly as a response to a crisis: Faith is "a declarative act, as an enactment of the self, as a performative that proclaims itself into existence in a situation of crisis where what is called for is a decisive political intervention." (Critchley 2010, p. 13). Regarding nihilism, faith is the lived subjective commitment, and "fidelity to an infinite demand" in order to overcome a passive nihilism, a deeply essential optimism of utopia (Critchley 2010, p. 18). 
the first place hoped-for, and after the fact, uniquely eludes and absconds conscious memory's grasp. If Religion (via Chrétien) is an act whereby we respond to the call from out of nothingness and despair, then forgetting instantiates the possibility that we might have some influence in shaping our faith in this in-between, active-passive role of "letting". It is from out of our finitude (or in Chretien's case, our "wounding") that our (again, not merely regional) religion gains its relevance, and continues to operate on our behalf implicitly and without our conscious awareness. One aim of this paper has been to describe some of the positive aspects of forgetting, which have been eclipsed in our contemporary western philosophical context that has favored the moral "good" of memory.

If religion truly is the sine qua non of the human, if the human were not possible as such without religion, then this would entail that religion is also ever-active, with or without the human's awareness. The idea of an ever-operative religious drive within us all at first prompts us to think that the goal should be to make the implicit explicit; that is, to draw out, clarify, or explicate how one is religious at all times and places, with the aim of memoralizing our religious experiences. Building upon Heidegger's insights, this creates a problem that amounts here to a paradox: once the experience gets memorialized, we tend to forget it, and go on with another project. Instead, "forgetting" reminds us that faith is a never-ending life experience; it is essential to every aspect of life and is not limitable to only one aspect or region that one might call "religious." The aim of religious life thus is neither to become "more aware" and name everything and make it all explicit, nor to await some great "unveiling" of something new from an indefinite future. If homo religiosus does nothing to nurture its faith actively, it seems a passive nihilism and indifference to religion itself will set-in and fester the life of faith, gearing one's religious acts toward finite-instead of absolute-ends. Contrary to expectation, it is forgetting that can help nourish the life of faith by altering our meaningful present, which then brings some balance to how we relate with our own—generally latent—religion.

Funding: This article was made possible due to the generous support of two research grants from the Austrian Science Fund (FWF). It was conceived within the framework of the project "Secularism and its Discontents. Toward a Phenomenology of Religious Violence" [P 29599], and concluded within the project "Revenge of the Sacred: Phenomenology and the Ends of Christianity in Europe" [P 31919].

Conflicts of Interest: The author declares no conflict of interest.

\section{References}

Apollonius, Rhodius. 1971. The Voyage of Argo: The Argonautica. Translated by Emile Victor Rieu. Harmondsworth: Penguin Books.

Bloechl, Jeffrey. 2010. Being without God. In Words of Life: New Theological Turns in French Phenomenology. Edited by Bruce Ellis Benson and Norman Wirzba. New York: Fordham University Press, pp. 30-41.

Chrétien, Jean-Louis. 2000. The Wounded Word: The Phenomenology of Prayer. In Phenomenology and the "Theological Turn": The French Debate. Edited by Dominique Janicaud. New York: Fordham University Press, pp. 147-76.

Chrétien, Jean-Louis. 2002. The Unforgettable and the Unhoped For. Translated by Jeffrey Blochl. New York: Fordham University Press.

Chrétien, Jean-Louis. 2015. Under the Gaze of the Bible. Translated by John Marson Dunaway. New York: Fordham University Press.

Critchley, Simon. 2010. Faith of the Faithless: Experiments in Political Theology. New York: Verso Books.

Davis, Joshua. 2010. The Call of Grace: Henri de Lubac, Jean-Louis Chrétien, and the Theological Conditions of Christian Radical Phenomenology. In Words of Life: New Theological Turns in French Phenomenology. Edited by Bruce Ellis Benson and Norman Wirzba. New York: Fordham University Press.

Derrida, Jacques. 1998. Faith and Knowledge: The Two Sources of 'Religion' at the Limits of Mere Reason. In Religion. Edited by J. Derrida and G. Vattimo. Cambridge: Polity Press.

Eliade, Mircea. 1969. The Quest: History and Meaning in Religion. Chicago: University of Chicago.

Falque, Emmanuel. 2016. Crossing the Rubicon: The Borderlands of Philosophy and Theology. New York: Fordham University Press. 
Heidegger, Martin. 1934. Hölderlins Hymnen "Germanien" und "Der Rhein," GA 39. Frankfurt am Main: Vittorio Klostermann.

Heidegger, Martin. 1962. Being and Time. Translated by John Macquarrie, and Edward Robinson. New York: Harper \& Row.

Heidegger, Martin. 1977. Sein und Zeit. GA 2. Edited by Friedrich-Wilhelm von Herrmann. Frankfurt am Main: Vittorio Klostermann.

Heidegger, Martin. 1978. Phänomenologie und Theologie, 2nd ed. In Wegmarken. Frankfurt Am Main: Vittorio Klostermann.

Heidegger, Martin. 1980. Holzwege. Frankfurt am Main: Vittorio Klostermann.

Heidegger, Martin. 1987. Nietzsche: The Will to Power as Knowledge and as Metaphysics. Translated by J. Stambaugh, D. F. Krell, and F. A. Capuzzi. San Francisco: Harper and Row, vol. 3.

Heidegger, Martin. 1989. Beitrüage zur Philosophie, GA 65. Frankfurt am Main: Vittorio Klostermann.

Heidegger, Martin. 1992. Parmenides. Translated by André Schuwer, and Richard Rojcewicz. Bloomington: Indiana University Press.

Heidegger, Martin. 2000. Überwindung der Metaphysik. In GA 7, Vorträge und Aufsätze. Franfurt Am Main: Vittorio Klostermann.

Heidegger, Martin. 2002. Nietzsche's Word: 'God is Dead'. In Off the Beaten Track. Translated by Julian Young, and Kenneth Haynes. New York: Cambridge University Press.

Heidegger, Martin. 2010. The Phenomenology of Religious Life. Bloomington: Indiana University Press.

Hodge, Joanna. 2006. Phenomenologies of Faith and Hope. Journal of the British Society for Phenomenology 37: 37-52. [CrossRef]

Inwood, Michael. 1999. A Heidegger Dictionary. Oxford: Blackwell.

Joas, Hans. 2014. Faith as an Option: Possible Futures for Christianity. Stanford: Stanford University Press.

Kierkegaard, Soren. 1964. Works of Love: Some Christian Reflections in the Form of Discourses. Translated by Howard, and Edna Long. New York: Harper and Row.

Marion, Jean-Luc. 2002. Being Given: Towards a Phenomenology of Givenness. Stanford: Stanford University Press.

Moore, Ian Alexander. 2017. Gelassenheit, the Middle Voice, and the Unity of Heidegger's Thought. In Perspektiven mit Heidegger. Edited by Gerhard Thonhauser. Freiburg Germany: Karl Aber.

Niebuhr, Richard. 1993. Radical Monotheism and Western Culture: With Supplementary Essays. Louisville: John Knox Press.

Nietzsche, Friedrich. 1995. Unfashionable Observations. In The Complete Works of Friedrich Nietzsche. Edited by Ernst Behler. Stanford: Stanford University Press, vol. 2.

Plato. 1990. The Republic. In The Dialogues of Plato. Translated by B. Jowett. Oxford: Clarendon Press.

Prevot, Andrew L. 2015. Responsorial Thought: Jean-Louis Chrétien's Distinctive Approach to Theology and Phenomenology. The Heythrop Journal 56: 975-87. [CrossRef]

Rahner, Karl, and Johann Baptist Metz. 1963. Hoerer des Wortes: Zur Grundlegung einer Religionsphilosophie. München: Koesel.

Ricoeur, Paul. 1980. Essays on Biblical Interpretation. Translated by Lewis Seymour Mudge. Philadelphia: Fortress Press.

Scheler, Max. 2010. On the Eternal in Man. New Brunswick: Transaction Publishers.

Schmitt, Carl, George Schwab, and Tracy B. Strong. 2010. Political Theology: Four Chapters on the Concept of Sovereignty. Chicago: The University of Chicago Press.

Simmons, J. Aaron. 2017. Living Joyfully after Losing Social Hope: Kierkegaard and Chrétien on Selfhood and Eschatological Expectation. Religions 8: 33. [CrossRef]

Smith, James K. A. 2006. Who's Afraid of Postmodernism?: Taking Derida, Lyotard, and Foucault to Church. Grand Rapids: Baker Academic.

Smith, James K. A. 2013. Cultural Liturgies. How Worship Works 2. Grand Rapids: Baker Academic.

Steinbock, Anthony. 1999. The Problem of Forgetfulness in Michel Henry. Continental Philosophy Review 32: 271-302. [CrossRef]

Tillich, Paul. 2009. Dynamics of Faith. New York: Harper One.

Troeltsch, Ernst. 1910. Die Zukunftsmöglichkeiten des Christentums. Logos 1: 165-85.

Troeltsch, Ernst. 1925. Das Verhältnis des Protestantismus zur Kultur. Über-blick. In Gesammelte Schriften. Tübingen: Tübingen Verlag, vol. 4. 
Volf, Miroslav. 2006. The End of Memory: Remembering Rightly in a Violent World. Grand Rapids: Eerdmans Publishing. Balthasar, Hans urs. 1982. Glory of the Lord I: Seeing the Form. Translated by Erasmo Leiva-Merikakis. Edinburgh: T \& T Clark.

Westphal, Merold. 1991. Kierkegaard's Phenomenology of Faith as Suffering. In Writing the Politics of Difference. Edited by Hugh J. Silverman. Albany: State University of New York Press.

Westphal, Merold. 2001. Overcoming Onto-Theology: Toward a Postmodern Christian Faith. New York: Fordham University Press.

Westphal, Merold. 2009. Hermeneutics and Holiness. In Analytic Theology: New Essays in the Philosophy of Theology. Edited by Oliver D. Crisp and Michael C. Rea. Oxford: Oxford University Press.

(C) 2019 by the author. Licensee MDPI, Basel, Switzerland. This article is an open access article distributed under the terms and conditions of the Creative Commons Attribution (CC BY) license (http://creativecommons.org/licenses/by/4.0/). 